\title{
Quality of Vermicompost Obtained from Residues of Forestry and Livestock
}

\author{
Ofelia Adriana Hernández-Rodríguez (Corresponding author) \\ Agrotechnology Sciences Department, Universidad Autónoma de Chihuahua \\ Ciudad Universitaria s/n, Campus No. 1, C.P. 31310 Chihuahua, México \\ Tel: 52-614-439-1844Ｅ-mail: aernande@uach.mx \\ Julio César López-Díaz \\ Agrotechnology Sciences Department, Universidad Autónoma de Chihuahua \\ Ciudad Universitaria s/n, Campus No. 1, C.P. 31310 Chihuahua, México \\ Tel: 52-614-439-1844Ｅ-mail: julio.lopez@uach.mx
}

Ana María Arras-Vota

Agrotechnology Sciences Department, Universidad Autónoma de Chihuahua

Ciudad Universitaria s/n, Campus No. 1, C.P. 31310 Chihuahua, México

E-mail: aarras@uach.mx

Jesús Quezada-Solís

Agrotechnology Sciences Department, Universidad Autónoma de Chihuahua

Ciudad Universitaria s/n, Campus No. 1, C.P. 31310 Chihuahua, México

E-mail: chuykezada@hotmail.com

\section{Dámaris Ojeda-Barrios}

Agrotechnology Sciences Department, Universidad Autónoma de Chihuahua

Ciudad Universitaria s/n, Campus No. 1, C.P. 31310 Chihuahua, México

E-mail: dojeda@uach.mx

$\begin{array}{ll}\text { Received: November 22, } 2011 & \text { Accepted: January 5, } 2012 \quad \text { Published: February 1, } 2012 \\ \text { doi:10.5539/sar.v1n1p70 } & \text { URL: http://dx.doi.org/10.5539/sar.v1n1p70 }\end{array}$

\begin{abstract}
The forestry-livestock waste materials represent a serious ecological problem if they are not handled properly in agricultural activities. Vermicomposting is a biotechnological process with potential to transform such materials into products that can be safely used as soil enhancers. The objective of this study was to evaluate the nutritional characteristics of organic fertilizers obtained from forestry-livestock organic waste materials when they are processed through vermicomposting using "Red Californian Earthworm" (Eisenia fetida). A completely randomized experimental design with four treatments and eight replicates was performed. Treatments (mixtures) included: leaf litter + sawdust (LS), bovine manure + sawdust (BS), rabbit manure + sawdust (RS), and ovine manure + sawdust (OS). Total nitrogen, $\mathrm{pH}$, carbon/nitrogen ratio, organic carbon and nitrates from vermicompost samples were measured and statistically analyzed using SAS v8.2. At the end of the study, all mixtures showed similar characteristics according to the analyzed variables. Carbon/nitrogen ratios decreased in three mixtures to values considered as within the vermicompost maturity stage. Contents of nitrates and total nitrogen were
\end{abstract}


increased. Final $\mathrm{pH}$ showed statistical difference among all mixtures. Results indicate that vermicomposting is a viable process for recycling forestry-livestock organic waste materials since it improves their chemical and nutritional characteristics.

Keywords: Eisenia fetida, Vermicompost, Agricultural amendment, Biotechnological process, Recycling, Organic waste

\section{Introduction}

Forestry-livestock organic residues represent a serious ecological problem if they are not handled properly in agricultural activities. Agriculture, cattle farming and forestry are important economical activities in the state of Chihuahua, Mexico. In accordance to official information, Chihuahua has recorded 1708887 bovines; 79050 hogs; 1808335 poultry (INEGI, 2007); 203757 goats; 131712 horses and 86621 sheep (INEGI, 2004), which generate significant quantities of manure. Also, the timber industry has enormous losses due to the low efficiency in the transformation processes, being sawdust one of the most important by-products (Zaragoza, 2004). These economical activities produce large quantities of waste materials that can be transformed into pollutants, causing ecological problems as a consequence (i.e. soil salinization, nitrate and phosphate lixiviation to underground waters and accumulation of lignin, aromatic oils and resins).

Although agricultural and forestry waste materials constitute a potential source of contaminants causing human health problems, they can also be seen as a new industry with extensive applications. An alternative for diminishing the environmental impact when using organic waste materials is their treatment by means of vermicomposting with "Red Californian Earthworm" (Eisenia fetida) which carries out a constant mixing and ventilation of materials, provides digestive enzymes and influences the decomposition characteristics of organic matter (Santamaría-Romero et al., 2001; Domínguez et al., 2003).

In the vermicomposting process, organic residues are decomposed by earthworms, diverse microorganisms and environmental factors. Carbon dioxide, water, mineral ions and stabilized organic matter are the most important products, the latter an enriched material with humic substances (Ulle et al., 2004). It has been demonstrated an increase on the nitrogen $(\mathrm{N})$ mineralization velocity as well as on the ammonium $\left(\mathrm{N}^{-} \mathrm{NH}_{4}{ }^{+}\right)$to nitrate $\left(\mathrm{N}^{-} \mathrm{NO}_{3}{ }^{-}\right)$ conversion index by the action of earthworms (Atiyeh et al., 2000a; Moreno, 2004). Diverse mixtures of organic residues processed by earthworms have been published, namely hog manure mixed with food remainders and bovine manure mixed with fruit fibers of oil palm, among many others (Hernández et al., 2008). Nogales et al. (2005) point out that vermicomposting is an excellent biotechnological process to produce agricultural amendments and that vermicompost is a chemically and biologically enriched material.

As a result of the vermicomposting process, organic waste materials are recycled into stabilized products that can be applied to soils as a relatively dry, odorless source of organic matter with the ability to meet the soil's organic fertility requirements in a safer and more efficient way than the incorporation of untreated materials (Soto \& Muñoz, 2002; Hernández, 2002). Nutritional properties of vermicompost can vary due to the different types and proportions of materials used, decomposition stage of such materials, vermicomposting conditions, and maturity and storage periods (Durán \& Henríquez, 2007).

Vermicompost from forestry-livestock residues seems to provide useful characteristics as a soil-improving material in ecological agriculture. In addition, vermicomposting process allows the elimination of pollution caused by manure, sawdust and leaf litter.

The objective of this study was to evaluate the nutritional characteristics of organic fertilizers obtained from forestry-livestock organic waste materials when they are processed through vermicomposting using "Red Californian Earthworm" (Eisenia fetida).

\section{Materials and Methods}

The study was conducted at the Agrotechnology Sciences Department, Universidad Autonoma de Chihuahua, Mexico. The decomposition process was undertaken for sixteen weeks (February to June, 2007). As nitrogen (N) source, four organic residues were used: bovine manure, rabbit manure, ovine manure and leaf litter. Pine's sawdust was used as carbon (C) source. Four treatments (mixtures) were prepared: leaf litter + sawdust (LS), bovine manure + sawdust (BS), rabbit manure + sawdust (RS), and ovine manure + sawdust (OS). All mixtures had an initial carbon/nitrogen $(\mathrm{C} / \mathrm{N})$ ratio of $25 / 1$, considered as an optimum ratio to initiate composting and vermicomposting processes (Hansen et al. 2001; Soto y Muñoz, 2002). To determine the required quantity of waste materials, the program "Moisture and C/N Ratio Calculation" developed by Richard (1995) was used.

The mixtures were deposited in 2-L plastic containers with 10-mm orifices in the bottom side to assure the draining of excessive humidity (Nogales et al., 2005; Santamaría-Romero et al., 2001). Initially, the mixtures were 
subjected to a 15-day pre-composting process to avoid possible damage to earthworms due to a temperature increase (Castillo et al., 2002). Later on, ten adult Red Californian Earthworms (Eisenia fetida) per liter per experimental unit were inoculated (Hernández et al., 2002). The study was conducted under laboratory conditions at $25^{\circ} \mathrm{C}$ temperature (Nogales et al., 2005) and 70-80\% humidity (Soto \& Muñoz, 2002).

Samples of vermicomposts were collected at weeks $4,8,12$ and 16 to quantify organic carbon (organic-C), total nitrogen (total- $\mathrm{N})$, nitrates $\left(\mathrm{N}^{-} \mathrm{NO}_{3}{ }^{-}\right)$and $\mathrm{pH}$ which are parameters needed to determine if a vermicompost fulfills the required standards for its use like a soil enhancer (García, 2006). To measure these parameters 200 grams of vermicompost were sampled, dried out in stove at $60^{\circ} \mathrm{C}$, sifted in No. 20 mesh and placed into polythene bags. Organic carbon was quantified by the ASTM method (2000), total-N by Micro-Kjeldahl method (APHA, 1992), $\mathrm{N}^{-\mathrm{NO}_{3}}{ }^{-}$by Brucine and UV-visible Spectrophotometry method (APHA, 1992) and $\mathrm{pH}$ by pHmeter (Fisher Scientific Accumet AB15, US®) using a water dilution of 1:5 (w/v).

A completely randomized experiment with four treatments and eight replicates was designed, which included the treatments and time as fixed effects. The results were statistically analyzed and means were compared by Tukey test $(\mathrm{P} \leq 0.05)$ using the software SAS version 8.20 (2004).

\section{Results and Discussion}

Vermicomposting significantly modified the observed characteristics of the initial mixtures. In general, vermicomposts obtained from the 16-wk decomposition process were more homogeneous, darker in color and odorless. These findings are similar to those previously published by other researchers (Soto \& Muñoz, 2002, Nogales et al., 2005).

The statistical analysis on the total-N evolution did not show effect on the treatment*time interaction $(\mathrm{P} \leq 0.4467)$ nor the treatment factor $(\mathrm{P} \leq 0.1339)$ (Figure 1). Nevertheless, the time factor showed a significant effect $(\mathrm{P} \leq$ 0.0320 ) on total-N concentration. The RS treatment showed the highest level of total-N at weeks 8 and 12 with values of $1.63 \pm 0.49$ and $1.84 \pm 1.41$ respectively, while OS treatment showed the highest level of total-N at weeks 4 and 16 with values of $1.63 \pm 1.05$ and $2.06 \pm 0.62$ respectively.

Total-N content of 16 -wk vermicomposts showed no statistical difference $(\mathrm{P}<0.2662)$ (Table 1$)$ but it increased as compared to its initial content, behavior expected as a result of: i) production of $\mathrm{N}$-containing metabolites by earthworms; ii) mucosity production, an N-enriched fluid excreted by earthworms; iii) N-enriched dead tissue; and iv) the mineralization process during vermicomposting (Del Aguila et al., 2011).

Castillo et al. (2002) observed total-N concentration of $1.25 \%$ in vermicompost obtained from bovine manure and means from 1.02 to $1.11 \%$ in mixtures of bovine manure + food remainders, while Barbados (2003) pointed out that the optimum interval for a vermicomposting process product is 1.0 to $2.6 \%$, as seen in the four treatments under study. Melgarejo et al. (1997) suggest an $\mathrm{N}$ content higher than $2 \%$ to allow the organic fertilizer for continuing its humification and mineralization process in the soil. According to Castillo et al. (2010), a 29-wk storage period without earthworms can increase the $\mathrm{N}$ content of recently elaborated organic fertilizers.

In the transformation process, organic-C content showed an effect on the treatment*time interaction $(\mathrm{P} \leq 0.0166)$ (Figure 1). As indicated before, this study started with mixtures containing $25 \%$ of initial organic-C which increased to values between 28 to $38 \%$ in a fluctuant fashion from week 4 . These findings coincide with Castillo (2002) who obtained $29.72 \%$ of organic-C content when using cattle and bovine manures. Such a behavior has been published by several researchers (Mondini et al., 2003) stating that the increase of organic-C concentration can be a result of the $\mathrm{C}$ usage from the initial organic residues by microorganisms in order to build new cellular materials, which can be re-used in the vermicomposting process later on, although such an increase do not coincide with Nogales et al. (2005) and Santamaría-Romero et al. (2001) who observed a decrease in organic-C content due to losses in the form of $\mathrm{CO}_{2}$ in the process.

At the end of this study, the organic-C content did not show statistical difference among treatments $(\mathrm{P}<0.0923)$ (Table 1). Del Aguila et al. (2011) stated that the organic-C decreases at the end of the vermicomposting process because of diverse factors: i) the organic-C consumption by earthworms; ii) the transformation in $\mathrm{CO}_{2}$ by respiratory activity; and iii) formation of the humic fraction which gives place to the mature vermicompost.

According to Barbados (2003), the optimum ranges for organic-C content vary between 30 to $40 \%$; nevertheless, other values must be taken into account to determine the maturity of vermicomposts, such as the $\mathrm{C} / \mathrm{N}$ ratio.

The $\mathrm{C} / \mathrm{N}$ ratio of the treatments under study did not show any effect on the treatment*time interaction $(\mathrm{P}<0.0739)$ (Figure 1), but there was a difference in the treatment factor $(\mathrm{P}<0.0145)$ and time factor $(\mathrm{P}<0.0393)$ because the LS treatment showed the highest means in weeks 4 and 12 with $\mathrm{C} / \mathrm{N}$ ratio of $50.04 \pm 14.6$ and $66.73 \pm 5.06$, respectively. The BS treatment showed the lowest mean at week 4 with $23.66 \pm 8.79$ value. RS and OS treatments 
showed mean values of 25.93 and 25.99 respectively. No difference existed among treatments on the $\mathrm{C} / \mathrm{N}$ ratio in the 16-wk transformation period $(\mathrm{P} \leq 0.1005)$ (Table 1).

The described changes of organic- $\mathrm{C}$ and total-N caused a decrease of the $\mathrm{C} / \mathrm{N}$ ratio in the LS, BS and OS treatments towards the end of the experimental period. The high $\mathrm{C} / \mathrm{N}$ values found in vermicompost of rabbit manure are possibly due to the high amounts of fiber surplus found in the animal diet which also remains in high quantities in the used raw material.

In accordance to several researchers, a compost is considered to be stable and mature when the $\mathrm{C} / \mathrm{N}$ ratio is lower than 20 (Nogales et al., 2005) or close to 15 (Acosta et al., 2004; Defrieri et al., 2005). In this study, the C/N ratio values indicate that the vermicompost maturity began towards the week 16 of the decomposition process.

The evolution of $\mathrm{N}^{-\mathrm{NO}_{3}}{ }^{-}$showed an effect in the treatment*time interaction $(\mathrm{P}<0.0478)$ (Figure 1). These significant differences were observed because the BS, RS and OS treatments initiated with $\mathrm{N}-\mathrm{NO}_{3}{ }^{-}$contents of 135 to $170 \mathrm{mg} \mathrm{kg}^{-1}$ at week 4 , increased at week 8 and finally decreased at weeks 12 and 16 . In comparison, LS treatment showed $226.75 \pm 43.17 \mathrm{mg} \mathrm{kg}^{-1}$ at week 4 , increased at week 8 to values of $317 \pm 27.92 \mathrm{mg} \mathrm{kg}^{-1}$, diminished at week 12 to $185.75 \pm 75.87 \mathrm{mg} \mathrm{kg}^{-1}$, and finally increased back again to $226.75 \mathrm{mg} \mathrm{kg}^{-1}$ at week 16 .

The $\mathrm{N}^{-N_{3}}{ }_{3}^{-}$content increase during the vermicomposting process suggests that the earthworms stimulate nitrification. For Atiyeh (2000b), such an increase suggests a higher maturation of the organic residues and it must be considered when incorporating organic residues to soils because $\mathrm{N}_{-} \mathrm{NO}_{3}{ }^{-}$is a negatively-charged ion which is not absorbed into the organic substrate or soil particles and can be leached out, contaminating water bodies as well as soils.

At the end of the experimental period, statistical significance in $\mathrm{N}^{-\mathrm{NO}_{3}}{ }^{-}$concentrations in vermicomposting treatments was not observed. $\mathrm{N}^{-\mathrm{NO}_{3}}{ }^{-}$concentrations showed values close to those seen in compost obtained from bovine manure and sawdust at the $99^{\text {th }}$ day with concentration of $330 \mathrm{mg} \mathrm{kg}^{-1}$ (Hao et al., 2004).

Values of $\mathrm{pH}$ for the four treatments showed an effect in the treatment*time interaction $(\mathrm{P}<0.0001)$ (Figure 1). The LS treatment, although it had a similar behavior, always showed less alkaline $\mathrm{pH}$ values in the four sampling periods, as compared to the other treatments. The OS treatment showed the highest $\mathrm{pH}$ mean, with value of 9.91. OS and RS treatments showed mean values of 8.99 and 9.30 , respectively. The four treatments showed significant differences in their final $\mathrm{pH}$ average values $(\mathrm{P}<0.0001)$ (Table 1).

Treatments showing $\mathrm{pH}$ values higher than 9 were those containing manure. In accordance to Barbados (2003), the $\mathrm{pH}$ of the substrate in the vermicomposting process plays a very important role on the earthworms because it has a direct influence in their feeding and reproductive functions, being $\mathrm{pH}$ values close to 7.0 (in a range from 5 to 8.5 ) preferred by earthworms.

On the matter, Santamaría-Romero et al. (2001) stated that earthworms die in substrates having pH values below 5 and above 9. In vermicompost, they also found an increase of $\mathrm{pH}$ values up to 8.7 at week 4 and 8.6 at week 16 . Several researchers explain that such an increase is due to the ingestion of decomposed organic residues by earthworms, which are chewed with their gizzards and then passed to the esophagus where calcareous glands are found with the function of excreting calcium carbonate to neutralize organic acids of the food (Ramirez, 2002).

These results are in accordance to Gutiérrez et al. (2007) who obtained $\mathrm{pH}$ values of 9.3 in bovine manure and 9.2 in ovine manure when evaluating the development of Eisenia fetida. In this study, a pH value higher than 9.0 seemed not to influence other variables since any statistical significance was found among the four treatments under evaluation.

\section{Conclusions}

The results of this laboratory study demonstrate that vermicomposting is a viable biotechnological process for recycling forestry-livestock organic waste materials because it decomposes and stabilizes such residues, contributing to diminish environmental problems. With regards to total- $\mathrm{N}$, organic- $\mathrm{C}, \mathrm{C} / \mathrm{N}$ ratio and $\mathrm{N}-\mathrm{NO}_{3}{ }^{-}$ significant differences among the four mixtures under study were not observed; however, there was an increase in total-N and $\mathrm{N}^{-\mathrm{NO}_{3}}{ }^{-}$content. Three treatments (LS, BS and OS) reduced their $\mathrm{C} / \mathrm{N}$ ratio to values between 18.03 and 19.81, which are considered to be within the interval for mature vermicomposts. In addition, difference in $\mathrm{pH}$ values existed with highest values corresponding to mixtures containing bovine, rabbit and ovine manure. These changes provide added value to forestry-livestock residues since vermicomposts can be utilized as enhancers for soils, especially for those with low content of organic matter. 
Finally, more research is suggested in this field, since the parameters can vary depending on the season of the year, type of organic residues and mixtures used, as well as on the period of time that such residues are subjected to the vermicomposting process.

\section{References}

Acosta, Y., Paolini, J., \& Benítez, E. (2004). Índice de humificación y prueba de fitotoxicidad en residuos orgánicos de uso agrícola potencial. Rev. Fac. Agron., 21(4), 1-6.

Alidaddi, H., Parvaresh, A. R., Shahmansoun, M. R., \& Pourmoghadas, H. (2005). Combined compost and vermicomposting process in the treatment and bioconversion of sludge. Iran. J. Environ. Health Sci. \& Eng., 2(4), 251-254.

American Public Health Association. (1992). Standard methods for the examination of water and wastewater. Method 4500- $\mathrm{NO}_{3}{ }^{-}$Part E. 4500- $\mathrm{NH}_{3}$ E. 18th Edition. Washington, D. C.

Atiyeh, R. M., Subler, S., Edwards, C. A., Bachman, G., Metzger, J. D., \& Shuster, W. (2000a). Effects of vermicomposts and composts on plant growth in horticultural container media and soil. Pedobiologia. 44, 579-590. http://dx.doi.org/10.1078/S0031-4056(04)70073-6

Atiyeh, R. M., Domínguez, J., Subler, S., \& Edwards, C. A. (2000b). Changes in biochemical properties of cow manure during processing by earthworm (Eisenia andrei, Bouché) and the effects on seedlings growth. Pedobiología. 44, 709-724. http://dx.doi.org/10.1078/S0031-4056(04)70084-0

American Society for Testing and Materials. (2000). Standard test methods for moisture, ash and organic matter of peat and other organic soils. Method D 2974-00. West Conshohocken, Pennsylvania, USA. D2974-00.

Barbados, J. L. (2003). Cría de lombrices. 1ra. Edición. Editorial Albatros. Buenos Aires. Argentina.

Castillo, A. E., Quarín, S. H., \& Iglesias, M. C. (2002). Caracterización química y física de compost de lombrices elaborados a partir de residuos orgánicos puros y combinados. Agricultura Técnica., 60(1), 74-79. http://dx.doi.org/10.4067/S0365-28072000000100008

Castillo, H., Hernández, A., Domínguez, D., \& Ojeda, D. (2010). Effect of californian red worm (Eisenia foetida) on the nutrient dynamics of a mixture of semicomposted material. Chil. J. Agr. Res., 70(3), 465-473. http://dx.doi.org/10.4067/S0718-58392010000300014

Defrieri, R. L., Jiménez, M. P., Effron, D., \& Palma, M. (2005). Utilización de parámetros químicos y microbiológicos como criterios de madurez durante el proceso de composteo. AgriScientia, 22, 25-31.

Del Aguila, J. P., Lugo, F. J., \& Vaca, P. R. (2011). Vermicomposting as a process to stabilize organic waste and sewage sludge as an application for soil. Tropical and subtropical Agroecosistems, 14, 949-963.

Domínguez, J., R., Parmelee, W., \& Edwards, C. A. (2003). Interactions between Eisenia andrei (Oligochaeta) and nematode populations during vermicomposting. Pedobiologia, 47, 53-60. http://dx.doi.org/10.1078/0031-4056-00169

Durán, L., \& Henríquez, C. (2007). Caracterización química, física y microbiológica de vermicompostes producidos a partir de cinco sustratos orgánicos. Agron. Costarricense, 31(001), 41-51.

García, P. R. E. (2006). La lombriz de tierra como biotecnología en agricultura. Tesis de licenciatura. Universidad Autónoma de Chapingo. México.

Gutiérrez, V. E., Juárez, C. A., Mondragón, A. J., \& Rojas, S. L. (2007). Dinámica poblacional de la lombriz Eisenia foetida en estiércol composteado y fresco de bovino y ovino. Redvet VIII, 7, 1-8.

Hansen, B., Alroe, H. F., \& Kristensen, E. S. (2001). Approaches to assess the environmental impact of organism farming with particular regard to Denmark. Agric. Ecosyst. Environ, 83, 11-26. http://dx.doi.org/10.1016/S0167-8809(00)00257-7

Hao, X., Chang, C., \& Larney, F. J. (2004). Carbon and nitrogen balances and greenhouse gas emission during cattle feedlot manure composting. J. Environ. Qual., 33, 37-44. http://dx.doi.org/10.2134/jeq2004.0037

Hernández, J. A., Mayarez, L., Romero, E., Ruiz, J., \& Contreras, C. (2002). Efecto de la altura del cantero sobre el comportamiento de la lombriz roja (Eisenia spp). Lombricultura y abonos orgánicos Memorias. UAEM. México.

Hernández, A., Guerrero, F., Mármol, L., Bárcenas, J., \& Salas, E. (2008). Caracterización física según granulometría de dos vermicompost derivados de estiércol bovino puro y mezclado con residuos de fruto de la palma aceitera. INCI, 33(9), 668-671. 
Instituto Nacional de Estadística, Geografía e Informática. (2004). Anuario Estadístico. Chihuahua. Edición 2004. Gobierno Estado de Chihuahua. ISSN 0188-8668.

Instituto Nacional de Estadística, Geografía e Informática. (2007). VIII Censo Agrícola, Ganadero y Forestal 2007. Entidad Chihuahua. from http://www.google.com.mx/\#hl=es\&source=hp\&q=Instituto+Nacional+de+Estad\%C3\%ADstica\%2C+Geograf\% $\mathrm{C} 3 \% \mathrm{ADa}+\mathrm{e}+$ Historia $+(\mathrm{INEGI}) .+2007 .+\mathrm{VIII}+\mathrm{Censo}+\mathrm{Agr} \% \mathrm{C} 3 \% \mathrm{ADcola} \% 2 \mathrm{C}+$ Ganadero $+\mathrm{y}+$ Forestal++2007.++ Entidad + Chihuahua

Melgarejo, M. R., Ballesteros, M. I., \& Bendeck, M. (1997). Evaluación de algunos parámetros fisicoquímicos y nutricionales en humus de lombriz y derivados de composta. Revista Colombiana de Química, 26(2), 1-11.

Mondini, C., Dell' Abate, M. T., Leita, L., \& Benedetti, A. (2003). An integral chemical, thermal, and microbiological approach to compost stability evaluation. J. Environ. Qual., 32, 2379-2386. http://dx.doi.org/10.2134/jeq2003.2379

Moreno, R. A. (2004). La vermicomposta y su potencial para el desarrollo de especies vegetales. Memorias del IV Simposio Nacional de Horticultura. México.

Nogales, R., Cifuentes, C., \& Benítez, E. (2005). Vermicomposting of winery wastes: A laboratory study. J. Environ. Sci. Health, 34, 659- 673.

Ramírez, S. L. F. (2002). Efecto de las lombrices en la calidad de los abonos orgánicos. Memorias del II Simposium Internacional y Reunión Nacional. UAEM.

Richard, T. L. (1995). Moisture and carbon/nitrogen ratio calculation. Cornell Waste Management Institute, Department of Agricultural and Biological Engineering. Recovered from http://compost.css.cornell.edu/calc/lignin.html

Santamaría-Romero, S., Ferrera, C. R., Almaraz, S. J., Galvis, S. A., \& Barois, B. I. (2001). Variación y relaciones de microorganismos, C-orgánico y N-total durante el composteo y vermicomposteo. Agrociencia, 35(4), 377-384.

Soto, G., \& Muñoz, C. (2002). Consideraciones teóricas y prácticas sobre el Compost, y su empleo en la Agricultura. Manejo integrado de plagas y Agroecología, 65, 123-125.

Ulle J., Fernandez, F., \& Rendina, A. (2004). Evaluación analítica del vermicompost de estiércoles y residuos de cereales y su efecto como fertilizante orgánico en el cultivo de lechugas mantecosas. Horticultura Brasileira, 22(2), 434-438.

Zaragoza, E. A. (2004). Avance última Milla "Madera líquida". CIMAV. Centro de Investigación en Materiales Avanzados. Chihuahua, México. Recovered from http://www.conacyt.mx/avance/proyectos/propuesta_C01-81_2003.pdf

Table 1. Chemical characteristics of vermicomposts with a process of 16 weeks.

\begin{tabular}{|c|c|c|c|c|c|c|}
\hline \multirow[t]{2}{*}{ Vermicompost } & & Total-N & Organic-C & \multirow[t]{2}{*}{$\mathrm{C} / \mathrm{N}$} & \multirow{2}{*}{\multicolumn{2}{|c|}{$\begin{array}{l}\mathrm{N}^{-\mathrm{NO}_{3}}{ }^{-} \\
\mathrm{mg} \mathrm{kg}^{-1}\end{array}$}} \\
\hline & & \multicolumn{2}{|r|}{$\%$} & & & \\
\hline Leaf litter + sawdust & LS & $1.68 \mathrm{a}$ & $31.1 \mathrm{a}$ & $19.34 \mathrm{a}$ & $222 \mathrm{a}$ & $8.16 \mathrm{c}$ \\
\hline Bovine manure + sawdust & BS & $1.58 \mathrm{a}$ & $31.1 \mathrm{a}$ & $19.81 \mathrm{a}$ & $235 \mathrm{a}$ & $9.10 \mathrm{~b}$ \\
\hline Rabbit manure + sawdust & RS & $1.46 \mathrm{a}$ & $38.0 \mathrm{a}$ & $26.80 \mathrm{a}$ & $235 \mathrm{a}$ & $9.44 \mathrm{a}$ \\
\hline Ovine manure + sawdust & OS & $1.46 \mathrm{a}$ & $35.1 \mathrm{a}$ & $18.03 \mathrm{a}$ & 249 a & $9.26 \mathrm{a}$ \\
\hline
\end{tabular}

${ }^{\mathrm{ab}}$ Averages with same letter in same column do not differ statistically (Tukey $\mathrm{P} \leq 0.05$ ). 

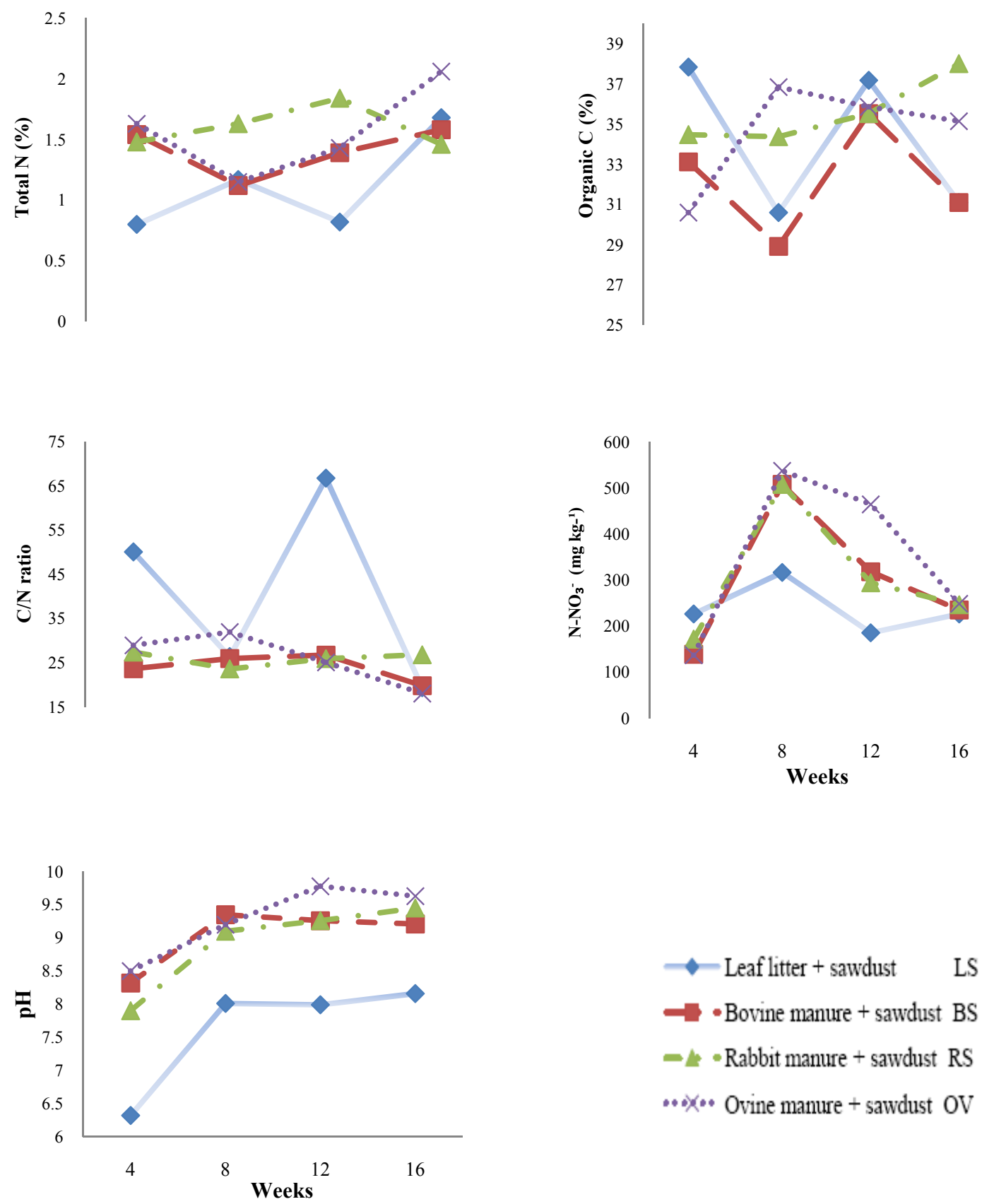

Figure 1. Dynamics of value averages for: a) total-N, b) organic-C, c) $\mathrm{C} / \mathrm{N}$ ratio, d) $\mathrm{N}_{-} \mathrm{NO}_{3}{ }^{-}$and e) $\mathrm{pH}$, for vermicomposts under study 